\title{
聴神経腫瘍症例の神経耳科学的検討
}

\begin{tabular}{|c|c|}
\hline 鈴木 & 薰 · 加藤 \\
\hline 㨞 - 石神 & 寛通・㴰本 \\
\hline
\end{tabular}

\section{Neurootological Examinations in Patients with Acoustic Neurinoma}

\author{
Yukihiko Hyo, Kaoru Suzuki, Kazutoshi Kato, Ichio Inuzuka, \\ Shigeru Inafuku, Hiromichi Ishigami and Isao Takimoto
}

(Aichi Medical University)

\begin{abstract}
Preoperative neurootological examinations were conducted in 23 cases of acoustic neurinoma and the relation between tumor size and neurootological findings was investigated. Although there was no correlation between tumor size and hearing level or frequency characteristics, variations of gaze nystagmus were dependent on tumor size.
\end{abstract}

Key words: acoustic neurinoma, hearing level, gaze nystagmus

はじめに

ここ数年 MRI をはじめとする画像診断の発 達で聴神経腫瘍, 後頭蓋窩の腫瘍の早期診断が 可能となり, 当院でも症例数が増加してきてい る. 我々は昭和 59 年より平成 5 年 6 月までに当 院脳神経外科で手術治療された聴神経腫瘍症例 の症状, 聴力レベル, 聴力型, 各種聴覚機能検 査, 平衡機能検査につき腫瘍の大きさ別に検討 した.

\section{対象と方法}

上記期間に聴神経腫瘍で手術治療が行われた 23例を対象とした。な扡他に高齢のため手術を しなかった 1 例, 患者本人の都合等で他院で手 術を行った 3 例があるが, 今回の統計の対象外 とした。

\section{結 果}

(1)腫瘍の大きさ別の例数(表 1)

腫瘍の大きさの分類は橋本ら にによる分類に
基づき内耳道内腫瘍を $0 \mathrm{~mm}$ とし後頭蓋内の腫 瘍の長径により分類した. 内耳道内腫瘍が 4 例, 小腫瘍 6 例, 中腫瘍 8 例, 大腫瘍 4 例, 特大腫 瘍が 1 例計23例であった。

(2)自覚症状と腫瘍径(表 2)

難聴，耳鳴，耳閉感，回転性めまい，浮動性 めまいは, 腫瘍の大きさの如何を問わずすべて の例で認められた。味覚障害は 2 例とも中腫瘍 以上, 三叉神経症状は 5 例中 4 例が中腫瘍以上 にあった. 内耳道内腫瘍で三叉神経症状のあっ た 1 例は手術所見でも内耳道内に限局しており， 腫瘍に起因する症状とは考えにくかった.

(3)各種画像診断と腫瘍径

ステンバース法, 後頭前頭位法では中腫瘍以 上の 4 例では内耳道の拡大が明確でなかったが このらち内耳道断層撮影が施行された 3 例はい ずれも内耳道の桩大所見があった. 内耳道断層 撮影では施行18例全例内耳道の拡大所見があっ 
た. CT では内耳道内腫瘍, 小腫瘍は腫瘍が映 らない例もあり(施行 9 例中 5 例) 中腫瘍も 1 例 は内耳道の拡大所見のみみられた。 air CT は MRI 導入以前内耳道内腫瘍, 小腫瘍の描出に 用いたが現在は行っていない。

表 1 聴神経腫瘍の大きさ分類(橋本ら1)による)と 当科の例数

\begin{tabular}{lrr}
\hline \hline & 後頭蓋内長径 & 例数 \\
\hline IM(内耳道内) & $0 \mathrm{~mm}$ & 4 \\
Small(小腫瘍) & $1 \sim 15 \mathrm{~mm}$ & 6 \\
Medium(中腫瘍) & $16 \sim 30 \mathrm{~mm}$ & 8 \\
Large(大腫瘍) & $31 \sim 40 \mathrm{~mm}$ & 4 \\
X-Large(特大腫瘍) & $41 \sim \mathrm{mm}$ & 1 \\
& & 計
\end{tabular}

IM-Intrameatal
(4)平均聴力レベル (3 分法) と腫瘍径 (図 1)

X-Large の 1 例がさすがに壟であること以外 腫瘍の大きさと聴力レベルとの相関はこの結果 からは不明である.内耳道内腫瘍で $100 \mathrm{~dB}$ を 越える例がある一方, 壟の 3 例はいずれも中腫 瘍以上の大きさであった。

(5)聴力型と腫瘍径(表 3，表 4)

聴力型は神崎2)の分類, 定義に従った．高音 急檠型が最も多く 5 例, 以下山型 4 例, 谷型 3 例，龍 3 例と続いていた。 山型がいずれも中腫 痬である他に，(4)で書いた様に龔の 3 例は中腫 瘍以上の大きさにみられた。山型と中腫瘍の相 関は例数が少ないので不明である。

6)聴力レベルの経過と腫瘍径(表 5 )

難聴は徐々に進行する例が最も多かった．聴 カレベルが変動した 3 例は内耳道内腫瘍 2 例,

表 2 自覚症状と腫瘍径

\begin{tabular}{lcccccc}
\hline \hline & IM & Small & Medium & Large & X-Large & 計 \\
\hline 難 聴 & 4 & 6 & 6 & 4 & 1 & 21 \\
耳 鳴 & 3 & 6 & 5 & 3 & 0 & 17 \\
耳閉感 & 1 & 2 & 4 & 1 & 0 & 8 \\
回転性めまい & 1 & 1 & 1 & 1 & 0 & 4 \\
浮動性めまい & 2 & 3 & 3 & 1 & 0 & 9 \\
三叉神経症状 & 1 & 0 & 2 & 1 & 1 & 5 \\
味覚障害 & 0 & 0 & 1 & 1 & 0 & 2
\end{tabular}

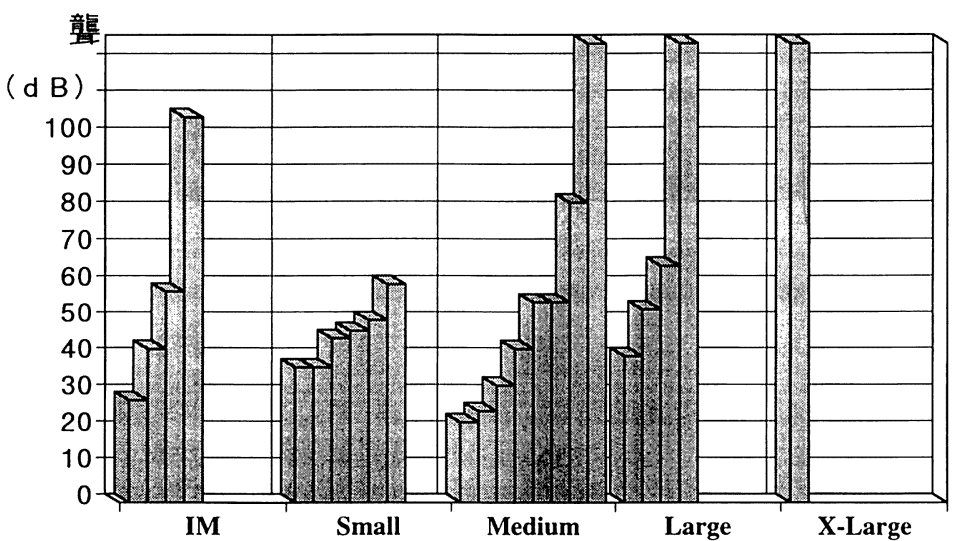

図 1 平均聴カレベルと腫瘍の大きさ 
小腫瘍 1 例で小さな腫瘍に認められた.

(7) 各種聴覚機能検査

全例には行っていないが SISI は 6 例中 4 例 が陽性, ABLB は10例中 3 例が陽性, TTDT は11例中 6 例が陰性, 自記オージオメトリーで は Jerger III, $\mathbb{N}$ 型は15例中 4 例で， I 型は 4 例, II 型は 7 例であった. 4 種類の検査のらち 自記オージオメトリーを含む 3 種類以上の検査 がなされた11例中 3 例がすべて内耳性で一致し， 3 例がすべて後迷路性で一致した。適切な test-battery と総合評価の必要な所以である.
表 5 耳症状の発現様式と腫瘍の大ささ

\begin{tabular}{|c|c|c|c|}
\hline & 徐々に進行 & 突発 & 変動 \\
\hline $\mathrm{IM}$ & 2 & 0 & 2 \\
\hline Small & 4 & 1 & 1 \\
\hline Medium & 7 & 1 & 0 \\
\hline Large & 4 & 0 & 0 \\
\hline X-Large & 1 & 0 & 0 \\
\hline 計 & 18 & 2 & 3 \\
\hline
\end{tabular}

表 3 聴力像の分類(神崎 ${ }^{2}$ による)

\footnotetext{
水平型 : 隣接する周波数での聴カレベル差が $10 \mathrm{~dB}$ 以内で, かつ $250 \mathrm{~Hz}$ から $4 \mathrm{kHz}$ までの聴力レベルの差 が $20 \mathrm{~dB}$ 以内のもの

高音漸傾型：全体として高音域ほど聴力レベルが上昇するが，隣接する周波数での聴カレベル差が $15 \mathrm{~dB}$ 以 内のもの

高音急墜型：全体としては高音域ほど聴力レベルが上昇するもので，高音漸傾型を除いたもの

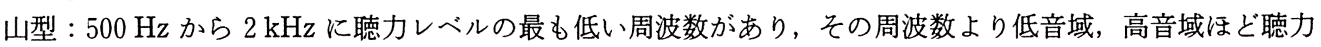

$$
\text { レベルが上昇するもの }
$$

谷型： $500 \mathrm{~Hz}$ から $2 \mathrm{kHz}$ に聴力レベルの最も高い周波数があり，その周波数より低音域，高音域ほど聴力$$
\text { レベルが低下するもの }
$$

低音障害型：全体として低音域ほど聴力レベルが上昇し，隣接する周波数での聴力レベル差が $10 \mathrm{~dB}$ 以上の もの

dip 型 : $250 \mathrm{~Hz}$ から $4 \mathrm{kHz}$ までの 1 周波数の聴力レベルが隣接する周波数の聴力レベルより $20 \mathrm{~dB}$ 以上上昇 するもの

魂： 7 周波数すべての聴力がスケールアウトのもの

脰型： 7 周波数すべてがスケールアウトではないが壟に近い高度難聴であるもの

不定型：その他のもの
}

表 4 聴力型と腫瘍の大ささ

\begin{tabular}{|c|c|c|c|c|c|c|}
\hline & IM & Small & Medium & Large & $X$-Large & 計 \\
\hline 水平型 & 1 & 1 & 0 & 0 & 0 & 2 \\
\hline 高音急隥型 & 1 & 1 & 1 & 2 & 0 & 5 \\
\hline 山型 & 0 & 0 & 4 & 0 & 0 & 4 \\
\hline 谷型 & 1 & 1 & 1 & 0 & 0 & 3 \\
\hline 低音障害型 & 0 & 0 & 0 & 1 & 0 & 1 \\
\hline$d i p$ 型 & 0 & 1 & 1 & 0 & 0 & 2 \\
\hline 眐 & 0 & 0 & 1 & 1 & 1 & 3 \\
\hline 型型 & 1 & 0 & 0 & 0 & 0 & 1 \\
\hline 不定型 & 0 & 2 & 0 & 0 & 0 & 2 \\
\hline
\end{tabular}


8)耳小骨筋反射と腫瘍径(表 6 )

20例中16例に無反応，波形逆転の異常所見を 得た. 一方, 内耳道内腫瘍, 小腫瘍のらち 4 例 は良好な反応をした。これは反応良好であるか らといって聴神経腫瘍を否定できない注意点と いえる。

\begin{tabular}{|c|c|c|}
\hline & $\begin{array}{c}\text { 何らかの異常 } \\
\text { 所見 }\end{array}$ & 反応良 \\
\hline IM & 3 & 1 \\
\hline Small & 2 & 3 \\
\hline Medium & 6 & 0 \\
\hline Large & 4 & 0 \\
\hline X-Large & 1 & 0 \\
\hline 計 & 16 & 4 \\
\hline
\end{tabular}

(9)ABR

$\mathrm{V}$ 波潜時左右差 (IT5) の正常限界を $0.2 \mathrm{msec}$ とし, $4 \mathrm{kHz}$ 純音域值が $50 \mathrm{~dB}$ を超す症例では $10 \mathrm{~dB}$ ごとに $0.1 \mathrm{msec}$ 足していく基準をあて はめた。 また波形の一部消失，無反応も異常所 見とした. 21例中20例に異常所見が認められた。 (10)注視眼振検查と腫瘍径(表 7)

左右側方注視眼振, Bruns-Cushing 眼振は中 腫瘍, 大腫瘍の 2 例にみられた.内耳道内腫瘍 で指標追跡検査における滑動性不良例は自発眼 振が superinpose されたと考えた。中腫瘍以上 では Bruns-Cushing 眼振, 左右側方注視眼振, 指標追跡検査の滑動性不良例等がみられ脳幹へ の影響が示唆された。

(11) 頭位眼振検査と腫瘍径 (表 8)

眼振の方向, 性状で検討した，患側向き，健 側向きはほぼ同数で，また水平回旋混合性眼振 8 例, 水平性眼振 5 例で水平性成分の眼振が多 く観察された．小腫瘍の下眼瞼向き眼振は腫瘍

表 7 注視眼振と腫瘍の大きさ

\begin{tabular}{lcccccc}
\hline \hline & IM & Small & Medium & Large & X-Large & 計 \\
\hline 左右側方注視眼振 & 0 & 0 & 0 & 1 & 0 & 1 \\
Bruns-Cushing 眼振 & 0 & 0 & 1 & 0 & 0 & 1 \\
健側向き眼振 & 0 & 0 & 1 & 0 & 0 & 1 \\
滑動性不良 & 1 & 0 & 1 & 1 & 0 & 3 \\
な ᄂ & 3 & 6 & 4 & 2 & 1 & 16
\end{tabular}

表 8 頭位眼振と腫瘍の大きさ

\begin{tabular}{lcccccc}
\hline \hline 頭位眼振 & IM & Small & Medium & Large & X-Large & 計 \\
\hline 方 向 & 2 & 2 & 2 & 0 & 1 & 7 \\
$\quad$ 患側向き & 1 & 2 & 4 & 1 & 0 & 8 \\
$\quad$ 健側向き & 0 & 0 & 0 & 1 & 0 & 1 \\
$\quad$ 方向交代性上向性 & & & & & & \\
性 状 & 3 & 2 & 2 & 1 & 0 & 8 \\
$\quad$ 水平回旋混合性 & 0 & 1 & 3 & 0 & 1 & 5 \\
$\quad$ 水平性 & 0 & 0 & 1 & 0 & 0 & 1 \\
$\quad$ 回旋性 & 0 & 1 & 0 & 0 & 0 & 1 \\
$\quad$ 下眼瞼向き垂直 & 1 & 2 & 1 & 2 & 0 & 6 \\
眼振なし & & & & & &
\end{tabular}


のなんらかの中枢への影響が考えられた．

(12) 温度眼振検查と腫瘍径 (表 9)

$0^{\circ} \mathrm{C}$ 冷水でも反応のなかったのを完全麻痺, ある程度反応のあったのを反応低下とした．検 査施行21例中17例が完全麻疩あるいは反応低下 であった. 反応良好例は内耳道内腫瘍が 1 例, 小腫瘍が 2 例で中腫瘍の 1 例は反応良好であり， 診断上の注意点である.

(13)二点交互視検査

二点交互視検査は施行した11例全例正常であ った。

(14)指標追跡検査 (ETT)

検査施行11例中 7 例が良好, not smooth は 3 例で, 小腫瘍, 中腫瘍, 特大腫瘍それぞれ 1 例ずつであった. 小腫瘍で not smoothの 1 例 は眼振が superimpose されたものである. saccadic 例は中腫瘍, 大腫瘍にそれぞれ 1 例ずつ みられた. 小腫瘍で not smoothの1例を除き not smooth, saccadic 例は中腫瘍以上の大きさ にみられた。脳幹, 小脳への影響が示唆される 所見で予想通りの結果を得た.

(15)視運動性眼振検査 (OKP)

検査施行 11 例中良好は 6 例であった。解発不 良は小腫瘍 1 例, 中腫瘍 2 例, 大腫瘍, 特大腫 瘍それぞれ 1 例ずつで, overshootは中膿瘍に 1 例認められた。腫瘍で解発不良の例は, ETTで not smooth 例と同一例だが健側の
OKP が解発不良であった．原因は不明である． この例を除くと解発不良, overshoot 例は中腫 瘍以上の大きさに認められた，ETT と同様脳 幹, 小脳への影響が考えられた.

内耳道内腫瘍, 小腫瘍で二点交互視, ETT, OKPが行われていない症例が多く反省すべき 点である.

16術後平均聴力レベルと腫瘍径(表10)

壟には至っていないのを悪化とした。術後に 聴力検査をしていない 2 例, 術前より壟の 3 例 は除いてある．18例中12例が残念ながら壟にな っていた. 一方聴力レベルが保存できた 6 例は すべて内耳道内腫瘍，小腫瘍で，比較的小さな 腫瘍なら聴力レベルが保存できると考えた。

表10 術後聴力レベル

\begin{tabular}{r|c|c|c}
\hline \hline \multirow{2}{*}{\begin{tabular}{r} 
改善、不変 \\
\cline { 2 - 4 }
\end{tabular}} & \multicolumn{1}{c}{ 悪化 } & \multicolumn{1}{c}{ 童 } \\
\cline { 2 - 4 } Small & 1 & 1 & 1 \\
\cline { 2 - 4 } Medium & 0 & 0 & 6 \\
\cline { 2 - 4 } Large & 0 & 0 & 2 \\
\cline { 2 - 4 } X-Large & 0 & 0 & 0 \\
\cline { 2 - 4 } 計 & 3 & 3 & 12 \\
\hline
\end{tabular}

術前より犝であった例は除く

表 9 温度眼振検査

\begin{tabular}{|c|c|c|c|}
\hline & 患側完全麻㾝 & 患側反応低下 & 良 \\
\hline IM & 0 & 3 & 1 \\
\hline Small & 1 & 3 & 2 \\
\hline Medium & 3 & 2 & 1 \\
\hline Large & 0 & 4 & 0 \\
\hline X-Large & 1 & 0 & 0 \\
\hline 計 & 5 & 12 & 4 \\
\hline
\end{tabular}


考察

23例中22例に難聴，耳鳴，耳閉感等の耳症状 があった．耳症状のなかった中腫瘍の 1 例は浮 動性めまいを主訴としていた。回転性めまい, 浮動性めまいはどの大きさの腫瘍でも認められ た。味覚障害は中腫瘍以上に 2 例，三叉神経症 状は 5 例中 4 例が中腫瘍以上の大ささに認めら れた. 結果の項で述べたよらに内耳道内腫瘍の 三叉神経症状は他の原因が考えられこの 1 例を 除けば予想通りの結果であった. Stenvers 法, 後頭前頭位法, 内耳道断層撮影の内耳道判定基 準はValvassori ${ }^{3)}$ の基準に従った。単純撮影で は82\%の陽性率で, 陰性の 4 例中 3 例も断層撮 影では陽性所見を呈した。なお 1 例は断層撮影 を施行していない、単純撮影と断層撮影は診断 初期のスクリーニングには有効な手段である. CTでは内耳道内腫瘍，小腫瘍で施行された 9 例中 5 例が造影剂を併用しても腫瘍の描出がで きず，施設的，時間的な余裕があれば CTより む MRI を優先した方が診断には有効と考えて いる.

聴神経腫瘍の大きさと聴力レベルとの関係は 小松崎 ${ }^{4)}$, 神崎 ${ }^{2)}$, 太田 $5^{5)}$, 草刈 ${ }^{6)}$, 細川 ${ }^{7)}$,

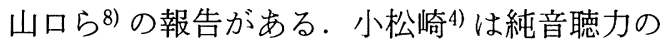
低下の程度と腫瘍の大きさはある程度相関があ ると述べているが, 神崎 ${ }^{2)}$ は腫瘍径と平均聴力 レベルとの間に明らかな関係は認められないと している.太田ら5) も腫瘍の大きさと聴力レベ ルは一定の関連はないとしている. 我々の症例 では龍の 3 例はいずれも中腫瘍以上に認められ， 聴力の変動する内耳道内腫瘍でも, 最悪化時は 平均聴力レベルが $105 \mathrm{~dB}$ になった。腫瘍の大 きさと聴力レベルには一定の傾向はないように 思われた。

聴力型は高音急墜型, 山型, 谷型, 竟の順に 少なくなった．襲を除き腫瘍の大きさとの相関 はなさそらである。細川ら7)は壟，高音障害型， 水平型が多くみられ, 太田ら5) は高音漸減型, 急墜型を含む高音障害型が高率に認められたと し, 草刈6)全襲, 高音障害が多い, そして
Johnson ${ }^{9)}$ も66\%が高音障害型だったとしてい る。また小池ら ${ }^{10)}$ は $2 \mathrm{kHz} ， 4 \mathrm{kHz}$ の障害が最 も強 $<, 1 \mathrm{kHz}$ も障害されているが $8 \mathrm{kHz}$ は $4 \mathrm{kHz}$ よりも軽度である高音障害血型難聴が半数近く を占めたとしている，その一方宮崎ら ${ }^{111}$ は聴 力型での偏りはなかったと報告している．腫瘍 の大きさとの関係に言及したものとしては神 崎2)が小腫瘍に谷型が多く認められたとしてい る. 当結果では谷型の 3 例とも中腫瘍以下であ るが例数が少なく，特徵的な結果といえるのか 否かわからない。

聴神経腫瘍の注視眼振に関して山口ら ${ }^{8)}$ は腫 瘍の増加に従って注視眼振なし $\rightarrow$ 定方向性眼振 (健側向き) $\rightarrow$ 左右注視方向性眼振 $\rightarrow$ 完全注視方 向性眼振へと進展するとしている．当結果でも 腫瘍が大きくなるに従い中枢への影響が示唆さ れる結果となった。

$$
\text { まとめ }
$$

(1)腫瘍の大きさと聴力レベルには一定の傾向 は認められなかった。

(2)聴力型で多いのは高音急墜型, 山型の順で, ついで谷型, 䆍が同数だった。

(3)注視眼振検査は腫瘍が大きくなるにつれ変 化が認められた。

\section{文献}

1) 橋本 省, 豊嶋 勝, 石垣元章, 他 : 経迷路聴 神経腫瘍摘出術の術後成績. Otol Jpn $2: 547$, 1992.

2）神崎 仁：聴神経腫瘍の外科的治療に関する研 究. 耳展 33 補 $3: 201 \sim 528,1990$.

3) Valvassori GE : Diagnosis of acoustic neuromas. Arch Otolaryngol $89: 285 \sim 289$, 1969.

4）小松崎篤 : 内耳道病変の臨床.「内耳道病変の 臨床」, 143 176頁, 東京医学社, 東京, 1987.

5）太田行紀, 吉田 茂, 鈴木 衞, 他: 広島大学 耳鼻咽喉科に打ける聴神経腫瘍の臨床的観察. 広島医学 $44: 1497 \sim 1501,1991$.

6）草刈 潤 : 聴神経腫瘍の早期診断について。耳 展 $31: 187 \sim 197,1988$.

7）細川 智, 井上鉄三, 平出文久, 他：聴神経腫 
瘍の聴力検査成績. 耳鼻臨床 $77: 715 \sim 722$, 1984.

8）山口宏也, 吉本 裕, 千葉康洋 : 聴神経腫瘍の 臨床的ならびに文献的考察(その 3 ). 耳喉 50 : 673 678, 1978.

9) Johnson EW : Auditory test results in 500 cases of acoustic neuroma. Arch Otolaryngol $103: 152 \sim 158,1977$.

10）小池修治, 橋本 省, 高橋 辰, 他 : 聴神経腫
瘍の聴力像. Otol Jpn 2 : 549, 1992.

11）宮崎千明, 永田雅英, 神崎順徳, 他 : 聴神経腫 瘍の臨床的観察. 耳鼻 $31: 765 \sim 771,1985$.

$$
\left(\begin{array}{c}
\text { 別刷請求先 : 兵 行彦 } \\
\boldsymbol{\mathbf { T }} 480-11 \text { 愛知県愛知郡長久手町 } \\
\text { 大字岩作字㕍又 } 21 \\
\text { 愛知医科大学耳鼻咽喉科学教室 }
\end{array}\right)
$$

